\title{
Effect of Inter and Intra Row Spacing on Growth, Yield Components and Yield of Hybrid Maize (Zea mays L.) Varieties at Haramaya, Eastern Ethiopia
}

\author{
Mekuannet Belay Kebede \\ School of Plant Sciences (Agronomy), Haramaya University, Haramaya, Ethiopia \\ Email: belaym2012@gmail.com
}

How to cite this paper: Belay, M.K. (2019) Effect of Inter and Intra Row Spacing on Growth, Yield Components and Yield of Hybrid Maize (Zea mays L.) Varieties at Haramaya, Eastern Ethiopia. American Journal of Plant Sciences, 10, 1548-1564. https://doi.org/10.4236/ajps.2019.109110

\section{Received: May 17, 2019}

Accepted: September 14, 2019

Published: September 17, 2019

Copyright $\odot 2019$ by author(s) and Scientific Research Publishing Inc. This work is licensed under the Creative Commons Attribution International License (CC BY 4.0).

http://creativecommons.org/licenses/by/4.0/

\begin{abstract}
The national average yield of maize is by far lower than the world average yield. Plant density is one of the factors that affect yield. Therefore, knowing the appropriate agronomic practices are paramount importance to maximize maize production in Ethiopia. A field experiment was conducted under rainfed conditions in 2015 and 2016 during the main cropping season at Haramaya to determine the effects of inter and intra row spacing on growth, yield components, and yield of hybrid maize varieties. The experiment consisted of the factorial combinations of two hybrid maize varieties ("BH-661" and "BH-QPY-545"), two inter-row spacing (65 and $75 \mathrm{~cm}$ ) and three intra-row spacing $(25,30$ and $35 \mathrm{~cm})$ in a $3 \times 2 \times 2$ factorial in a randomized complete block design experiment with three replications of each treatment combination. Aboveground dry biomass yield and grain yield were influenced by interaction effect of inter row spacing, intra row spacing and year. The highest aboveground dry biomass yield $\left(31.36 \mathrm{t} \cdot \mathrm{ha}^{-1}\right)$ and harvest index (47\%) were obtained for varieties BH-661 and BH-QPY-545 in 2016 and 2015, respectively. The highest aboveground dry biomass yield $\left(31.29 \mathrm{t} \cdot \mathrm{ha}^{-1}\right)$ and grain yield $\left(11.67 \mathrm{t} \cdot \mathrm{ha}^{-1}\right)$ were obtained in the combination of $75 \mathrm{~cm} \times 25 \mathrm{~cm}$ in 2016 cropping season. Therefore, it can be concluded that optimum inter and intra row spacing combination in the study area for the maximum grain yield was $75 \mathrm{~cm} \times 25 \mathrm{~cm}$ for both varieties under adequate amount and regular distribution of rainfall.
\end{abstract}

\section{Keywords}

BH-661, BH-QPY-545, Plant Density, Yield 


\section{Introduction}

Maize (Zea mays L.) is a member of the grass family, Poaceae. Maize is one of the most important cereal crops in the world. It ranks third in world production after wheat and rice [1]. Ethiopia is the fourth largest maize producing country in Africa, and first in the East African region in terms of production [2]. In view of its high demand for food grains and high yield per unit area, maize has been among the leading food grains selected to achieve food self-sufficiency in Ethiopia [2]. The major maize producing regions in Ethiopia are Oromia, Amhara, and Southern Nations Nationalities and Peoples' Regional State (SNNPRS) [3]. The 2017/18 Meher season post-harvest crop production survey indicated that the national level, $16.79 \%$ (about 2,128,948.91 hectares), of the land area was covered by maize and production of grain was about $27.43 \%$ or $83,958,87.24$ tons with an average yield of $3.9 \mathrm{t} \cdot \mathrm{ha}^{-1}$ [4]. Maize is the second important cereal crop in area coverage and production following sorghum, but first in productivity among the cereal crops in East Hararghe Zone [4]. Maize covered an area of about 43,078.05 ha; production of grain was 110,612 tons with an average grain yield of $2.57 \mathrm{t} \cdot \mathrm{ha}^{-1}$ in the Zone [4].

Even though maize has multiple purposes and high yielding potential, the national average yield $\left(3.67 \mathrm{t} \cdot \mathrm{ha}^{-1}\right)$ in general and the zonal yield $\left(2.57 \mathrm{t} \cdot \mathrm{ha}^{-1}\right)$ are low [4] as compared to developed countries' average yield which is about 6.2 t.ha ${ }^{-1}[3]$. The low productivity of maize is attributed to many factors such as poor agronomic practices like inappropriate seed rate, row and plant spacing, poor soil fertility, drought, insects, diseases and weeds, farmers' limited access to fertilizers, and low access to seeds of improved maize varieties [5]. Plant density is one of the factors that affect yield by influencing yield components such as the number of ears, the number of kernels per ear, and kernel mass [6]. Moreover, grain yield of maize is more affected by variations in plant population than other members of the grass family because of its low tillering ability [7]. Therefore, plant density and arrangement of plants in a unit area greatly determine resource utilization such as light, nutrients, and water; it affects the rate and extent of vegetative growth and development of crops particularly that of leaf area index, plant height, root length and density, yield and yield components, development of important diseases and pests, and the seed cost [8]. Because of this discrepancy, the establishment of required plant density is essential to get maximum yield since high plant density will deplete soil moisture and nutrients before the crop's maturity, whereas low plant density will leave nutrients unutilized [9]. Hence, optimum density will lead to the effective utilization of soil moisture and nutrients, etc. [9]. Optimum plant density for maximum grain yield per unit area may differ from hybrid to hybrid because of significant interactions between hybrids and densities [10]. However, in Ethiopia, maize spacing recommendation of 44,444 plants $\mathrm{ha}^{-1}(75 \mathrm{~cm} \times 30 \mathrm{~cm})$ has been used indiscriminately for a long time without taking into account the numerous morphological differences that exist among maize varieties as well as the existence of soil and climatic differences [11]. So it is important to determine the optimum plant density for 
maize hybrids depending on environmental factors (soil fertility, moisture supply) and agronomic management practices to get maximum yield [12]. In southern Ethiopia, a field experiment showed that varieties "BH-140", "BH-QPY-545" and "BH-540" gave the highest grain yield $\left(9.9 \mathrm{t} \cdot \mathrm{ha}^{-1}\right)$ at $65 \mathrm{~cm} \times 25 \mathrm{~cm}$ spacing as compared to $75 \mathrm{~cm} \times 30 \mathrm{~cm}$ spacing $\left(7.2 \mathrm{t} \cdot \mathrm{ha}^{-1}\right)$ [13]. Previous studies commented that the information on forming suitable plant density for each maize cultivar is one of the key factors for planning maize density to get maximum yield.

Therefore, the objective of this study was to determine the effect of inter and intra row spacing on growth, yield components and yield of maize hybrids.

\section{Materials and Methods}

\subsection{Description of the Experimental Site}

The experiment was conducted for two consecutive seasons (2015 and 2016) under rainfed conditions during the main cropping season at Raare, the research farm of Haramaya University. The site is located at $9^{\circ} 26^{\prime} \mathrm{N}$ latitude and $42^{\circ} 03^{\prime} \mathrm{E}$ longitude at an altitude of $1980 \mathrm{~m}$ above sea level. The rain distribution of the area is bimodal describe the months of the two seasons. The total amount of rainfall for the cropping season (May to October) in 2015 was $549.2 \mathrm{~mm}$ with the mean maximum and minimum temperatures of $25.6^{\circ} \mathrm{C}$ and $13.2^{\circ} \mathrm{C}$, respectively. The total amount of rainfall during 2016 cropping season was $628.6 \mathrm{~mm}$ and the mean temperature was $22^{\circ} \mathrm{C}$. The soil of the experimental site is a well-drained deep alluvial with a sub-soil stratified with sandy clay loam texture. The experiment soil consisted $\mathrm{pH} 7.84$, organic carbon $1.96 \%$, total nitrogen $0.12 \%$, available P9.94 mg. $\mathrm{kg}^{-1}$, CEC $25.98 \mathrm{cmol}(+) \mathrm{kg}^{-1}$ [14] (Figure 1).

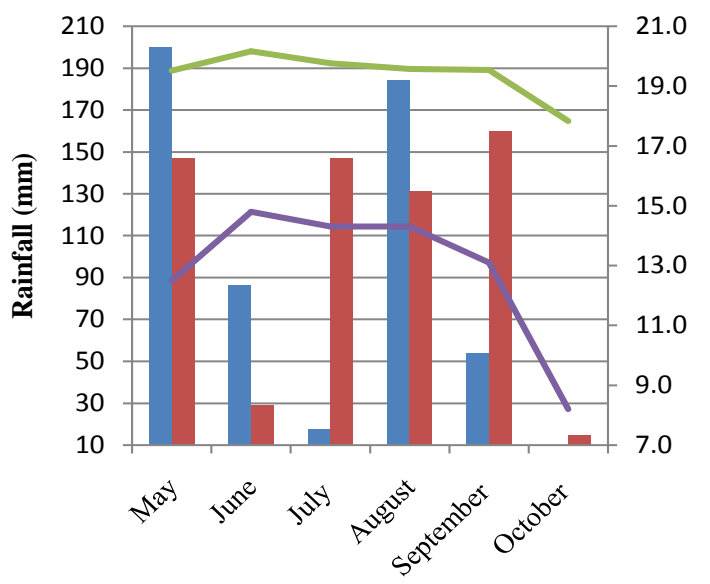

21.0

Months

$\overrightarrow{\mathbb{D}^{-1}} \quad$ Total monthly rainfall $(\mathrm{mm})$ in 2015

Total monthly rainfall (mm) in 2016

Monthly mean temperature $\left({ }^{\circ} \mathrm{C}\right)$ in 2015

Monthly mean temperature $\left({ }^{\circ} \mathrm{C}\right)$ in 2016

Figure 1. Total monthly rainfall $(\mathrm{mm})$ and monthly mean temperatures during the experimental cropping seasons (2015-2016) at Raare (Haramaya University).

\subsection{Description of Experimental Materials}

The maize hybrids used for the study are described below in Table 1 . 
Table 1. Description of the maize hybrids used in the experiment.

\begin{tabular}{|c|c|c|c|c|c|c|}
\hline \multirow[b]{2}{*}{ Variety } & \multicolumn{3}{|c|}{ Area of adaption } & \multirow[b]{2}{*}{ Maturity (days) } & \multicolumn{2}{|c|}{ Yield $\left(\mathrm{t} \cdot \mathrm{ha}^{-1}\right)$} \\
\hline & Year of relase & Altitude (m) & $\begin{array}{l}\text { Rain fall } \\
\text { (mm) }\end{array}$ & & On research & On farm \\
\hline BH-QPY-545 & 2008 & $1000-1800$ & $1000-1200$ & 144 & $8.0-9.5$ & $5.5-6.5$ \\
\hline BH-661 & 2011 & $1600-2200$ & $1000-1200$ & 160 & $9.5-12.0$ & $6.5-8.5$ \\
\hline
\end{tabular}

Sources: [15] [16].

\subsection{Treatments and Experimental Design}

The experiment was conducted using factorial combinations of two maize hybrids (BH-661 and BH-QPY-545), two inter-row (65 and $75 \mathrm{~cm}$ ) and three intra-row $(25,30$ and $35 \mathrm{~cm})$ spacing. Each plot had five rows of which three central rows were used for data collection and one row of each side of a plot was left as border effect. The experiment was conducted using a Randomized Complete Block Design in a factorial arrangement with three replications. Harvested net plot areas of 65 and $75 \mathrm{~cm}$ inter-row spacing were $4.2 \mathrm{~m} \times 1.95 \mathrm{~m}\left(8.19 \mathrm{~m}^{2}\right)$ and $4.2 \mathrm{~m} \times 2.25 \mathrm{~m}\left(9.45 \mathrm{~m}^{2}\right)$, respectively. The spacing of $1 \mathrm{~m}$ and $1.5 \mathrm{~m}$ were left between plots and blocks, respectively.

\subsection{Management of the Experiment}

After the land was well prepared, then two seeds per hole were sown in mid-May. All phosphorus fertilizer dose in the form of triple super phosphate (TSP) at the recommended rate of $100 \mathrm{~kg} \cdot \mathrm{ha}^{-1}\left(46 \mathrm{~kg} \mathrm{P}_{2} \mathrm{O}_{5} \mathrm{ha}^{-1}\right)$ and half of recommended rate of $\mathrm{N}$-fertilizer in the form of Urea $189 \mathrm{~kg} \cdot \mathrm{ha}^{-1}\left(87 \mathrm{~kg} \mathrm{~N} \mathrm{ha}^{-1}\right)$ were applied uniformly to all plots by band application method at the time of planting and the remaining half of $\mathrm{N}$-fertilizer was applied as of 50 days from sowing. Thinning to a single plant per each hill was done when seedlings produced three to four leaves. All other agronomic practices were applied uniformly as recommended for the crop.

\subsection{Data Collection and Measurements}

\subsubsection{Growth Parameters}

Leaf area per plant and leaf area index was recorded at $50 \%$ milk stage by measuring the leaf length and maximum leaf width of three leaves (top, middle, and bottom) per plant from five randomly taken plants from each net plot, the average of the three leaves was multiplied by the total number of leaves per plant and the area was adjusted by a correction factor 0.75 (i.e. $0.75 \times$ leaf length $\times$ maximum leaf width) as described by [17]. The leaf area index was determined as the ratio of leaf area per plant divided by the respective ground area occupied by the plant. Plant height was measured from ten randomly pre-tagged plants from the net plot area and then their height was measured from the soil surface to point where the tassel starts to branch with a meter rod at physiological maturity. Ear height was recorded from ten randomly pre-tagged plants from each net plot area and measured their ear height from the ground level to the node bearing the 
top useful ear with a meter rod at physiological maturity.

\subsubsection{Yield Components and Yield}

Stand count was recorded from the net plot area after thinning and at harvest. The final plant stand percentage (final plant stand counted at maturity/population established after thinning $\times 100$ ) of the respective treatments was used to determine the stand loss due to competition. Number of ears plant ${ }^{-1}$ were taken from ten randomly pre-tagged plants in the net plot area, and then their ears were counted at harvest and the average was recorded. Ear length was recorded from ten randomly taken ears from the net plot area and measured from the point where ears attached to the stalk to the tip of the ear with a glass ruler after harvest and the average was recorded. Ear diameter was recorded from ten randomly taken ears from the net plot area, and then their diameter was measured at the middle of ear with caliber ruler. The mean was recorded as ear diameter. Number of kernels ear ${ }^{-1}$ were recorded by multiplying the total number of rows per ear and the number of kernels per row from five randomly taken ears in the net plot area after harvest and the average was recorded. Thousand kernels were counted from randomly taken ears after shelling by using kernel counter (Contador $\mathrm{CE}$ ). Then, thousand kernels weight was recorded from weighed thousand kernels using sensitive balance and adjusted to $12.5 \%$ moisture level.

Above ground, dry biomass yield was weighed after entire plants harvested from the net plot area, weighed using field balance (Salter Model-235), and recorded biomass yield at harvest. Grain yield from the net plot area was weighed using field balance (Salter Model-235) and adjusted to $12.5 \%$ moisture, finally, it was converted into hectare. Harvest index was calculated as the ratio of grain yield to the total aboveground dry biomass yield per plot $\times 100$.

\subsection{Statistical Data Analysis}

All collected data were subjected to analysis of variance by using GenStat statistical software Release 15 [18]. For significant treatment effects, the mean separation was made using the Least Significance Difference (LSD) test at 5\% level of significance.

\section{Results and Discussion}

\subsection{Growth Parameters}

\subsubsection{Leaf Area Index}

Leaf area index was significantly $(\mathrm{P}<0.01)$ affected by three way interactions (variety $\times$ inter $\times$ intra). Therefore, a combined analysis of variance depicted that the maximum leaf area index (5.32) was obtained from variety BH-QPY-545 at closer inter $(65 \mathrm{~cm})$ and closestintra $(25 \mathrm{~cm})$ row spacing, whereas the minimum leaf area index (3.18) was attained from variety BH-661 at wider inter $(75 \mathrm{~cm})$ and widestintra $(35 \mathrm{~cm}$ ) row spacing (Table 2). The possible reason for the highest leaf area index for variety BH-QPY-545 at the narrowest inter and intra-row spacing might be due to more number of leaves produced owing to 
Table 2. Mean leaf area index of maize as affected by the interaction effect of varieties, inter and intra row spacing.

\begin{tabular}{ccccc}
\hline \multirow{2}{*}{ Variety } & Inter-row spacing $(\mathrm{cm})$ & \multicolumn{3}{c}{ Intra-row spacing $(\mathrm{cm})$} \\
\cline { 3 - 5 } & & 25 & 30 & 35 \\
\hline \multirow{2}{*}{ BH-661 } & 65 & $4.79^{\mathrm{f}}$ & $4.21^{\mathrm{de}}$ & $3.95^{\mathrm{cd}}$ \\
& 75 & $4.52^{\mathrm{ef}}$ & $3.47^{\mathrm{ab}}$ & $3.18^{\mathrm{a}}$ \\
\hline \multirow{3}{*}{ BH-QPY-545 } & 65 & $5.32^{\mathrm{g}}$ & $4.11^{\mathrm{de}}$ & $3.86^{\mathrm{bcd}}$ \\
& 75 & $4.49^{\mathrm{ef}}$ & $3.98^{\mathrm{cd}}$ & $3.57^{\mathrm{abc}}$ \\
\hline \multicolumn{4}{c}{} \\
\hline
\end{tabular}

Means in the table followed with the same letter(s) are not significantly different to each other at $5 \%$ level of significance; LSD $(0.05)=$ Least Significance Difference at $5 \%$ probability level; CV $=$ Coefficient of variation.

more number of plants per unit area. In line with this result, [19] reported the highest leaf area index (5.82) was obtained from variety Pioneer-30D55, while the lowest leaf area index (5.55) was obtained from variety pioneer-3012 due to less number of leaves per plant and less leaf breadth. Leaf area index also responded to the growing season, thus, the higher leaf area index (4.39) was recorded in 2015 cropping season than 2016 cropping season (3.86). The higher leaf area index in 2015 might be due to the presence of closer internode of plant produced more leaves owing to the low amount and erratic distribution of rainfall at early vegetative growth. Similarly, [20] revealed that leaf area index was significantly affected and increased in a linear fashion from 1.21 to 2.77 when plant population increased from 40,000 to 120,000 plants.ha ${ }^{-1}$ of maize, respectively. This was in agreement with [21] who showed that the leaf area index of maize was significantly affected by planting density and varieties, leaf area index increased from 2.5 to 3.5 as plant population increased from 45,000 to 65,000 plants.ha ${ }^{-1}$. [13] also showed that the highest leaf area index (4.19) was obtained at the narrowest plant spacing $(55 \mathrm{~cm} \times 25 \mathrm{~cm})$ and the lowest leaf area index (2.67) at the widest plant spacing $(75 \mathrm{~cm} \times 30 \mathrm{~cm})$ of maize.

\subsubsection{Plant and Ear Heights (cm)}

Plant height and ear heights were significantly $(\mathrm{p}<0.01)$ affected due to the main effect of variety and year. Accordingly, significantly taller plants $(239.0 \mathrm{~cm})$ and ear heights $(137.3 \mathrm{~cm})$ were obtained from the variety $\mathrm{BH}-661$ than variety BH-QPY-545 (Table 3). The differential growth with respect to plant height and ear height observed between the varieties might be attributed to differences in genetic characteristics of the individual varieties, including the height of the varieties. Similarly, [22] reported that various varieties of maize have genotypic differences for plant height where the tallest plant height $(145 \mathrm{~cm})$ was recorded for variety Cargill 707 and the shortest plant height $(134 \mathrm{~cm})$ was recorded for variety Baber. [23] also reported that ear heights of maize cultivars were significantly different and the greatest ear length $(144.1 \mathrm{~cm})$ was obtained from LG 2687 cultivar and the lowest ear height $(131.5 \mathrm{~cm})$ was obtained from a GH2547 
Table 3. Mean plant height, ear height, and leaf area index as influenced by the main effect of variety and year.

\begin{tabular}{ccc}
\hline & Plant height $(\mathrm{cm})$ & Ear height $(\mathrm{cm})$ \\
\hline Maize variety & $193.7^{\mathrm{b}}$ & $97.0^{\mathrm{b}}$ \\
BH-QPY-545 & $239.0^{\mathrm{a}}$ & $137.3^{\mathrm{a}}$ \\
BH-661 & 6.92 & 5.41 \\
LSD (0.05) & & \\
Year & $207.4^{\mathrm{b}}$ & $107.6^{\mathrm{b}}$ \\
2015 & $225.3^{\mathrm{a}}$ & $126.8^{\mathrm{a}}$ \\
2016 & 6.92 & 5.41 \\
LSD (0.05) & 6.70 & 9.70 \\
CV (\%) &
\end{tabular}

Means in columns followed with the same letter(s) are not significantly different from each other at a 5\% level of significance. LSD $(0.05)=$ Least Significance Difference at $5 \%$ probability level; CV $=$ Coefficient of Variation.

cultivar. [24] also reported that plant and ear heights are important yield determinant features in maize, the higher the ear height the more the number of ears that can develop from the nodes beneath.

On the other hand, combined analysis of variance indicated a significant difference in plant and ear heights due to the main effect of years. Therefore, significantly taller plant height $(225.3 \mathrm{~cm})$ and ear height $(126.8 \mathrm{~cm})$ were recorded in 2016 cropping season as compared to 2015 (Table 3). This discrepancy might be due to a more even rainfall distribution recorded in 2016 cropping season, which resulted in taller plants and ear length.

\subsection{Yield Components and Yield of Maize}

\subsubsection{Number of Ears per Plant}

Number of ears per plant were significantly $(p<0.01$ ) affected by the main effects of variety, inter-row spacing and interaction of intra row spacing by year and significantly $(\mathrm{p}<0.05)$ affected by the interaction effect of variety by inter-row spacing. The maximum number of ears per plant (1.95) were produced from variety BH-QPY-545 at a widerinter-row spacing $(75 \mathrm{~cm})$, while the lowest number of ears per plant (1.35) were produced from variety BH-661 at a closerinter-row spacing $(65 \mathrm{~cm})$ (Table 4). The result indicated that a number of ears per plant showed an increasing trend as inter-row spacing increased from 65 to $75 \mathrm{~cm}$ for both varieties. This could be due to the fact that at closer spacing or high plant densities, there may be intense intraspecific competition among plants for growth resources like nutrients, soil moisture, light, and carbon dioxide, thus, the supply of growth resources to growing ear is reduced in turn to reduce the number of ears per plant. High plant density creates competition for light, aeration, nutrients and consequently compelling the plants to undergo less 
Table 4. Mean number of ears per plant and grain yield of maize as affected by the interaction effect of variety and inter-row spacing.

\begin{tabular}{cccc}
\hline Variety & Inter-row spacing (cm) & Number of ears per plant & Grain yield $\left(\mathbf{t} \cdot \mathrm{ha}^{-1}\right)$ \\
\hline \multirow{2}{*}{ BH-661 } & 65 & $1.38^{\mathrm{a}}$ & $11.08^{\mathrm{b}}$ \\
& 75 & $1.45^{\mathrm{a}}$ & $9.99^{\mathrm{a}}$ \\
BH-QPY-545 & 65 & $1.63^{\mathrm{b}}$ & $9.57^{\mathrm{a}}$ \\
& 75 & $1.95^{\mathrm{c}}$ & $10.00^{\mathrm{a}}$ \\
LSD (0.05) & & 0.14 & 1.03 \\
CV (\%) & 12.8 & 15.20 \\
\hline
\end{tabular}

Means in the table followed with the same letter(s) are not significantly different from each other at $5 \%$ level of significance. LSD $(0.05)=$ Least Significance Difference at $5 \%$ probability level; CV $=$ Coefficient of Variation.

reproductive growth [25]. On the other hand, the maximum number of ears per plant in variety BH-QPY-545 might be due to the difference in the genetic makeup of two hybrids for this trait. This result was in conformity with those of [19] and [26] who observed that the number of ears per plant was significantly affected by plant population densities and variety.

The interaction effect intra row spacing and year had a significant $(\mathrm{p}<0.05)$ effect on number of ears per plant. The highest number of ears per plant (1.85) was produced where plants were sown at a widest intra row spacing $(35 \mathrm{~cm})$ in 2016 cropping season, while the lowest number of ears per plant (1.44) was produced in the same intra row spacing in 2015 cropping season (Table 5). The result showed that number of ears per plant revealed increasing trend as intra row spacing increased from 25 to $35 \mathrm{~cm}$ in 2016 cropping season but in 2015 cropping season this trend did not occur (Table 5). The higher number of ears at the widest intra-row spacing in 2016 cropping season might be due to adequate rainfall (was it high or the distribution was good? or both) that resulted in higher number of ears per plant at wider intra row spacing. Similarly, [27] and. [21] reported that wider-spaced maize plants obtained more soil moisture and nutrients than narrower plants that led to having a high number of ears per plant than narrow spacing. [25] also reported that with decreasing of plant spacing from $30 \mathrm{~cm}$ to $15 \mathrm{~cm}$, the number of ears per plant was significantly reduced from 1.42 to 1.21 possibly due to more competition for light, aeration and nutrients and consequently enabling the plants in closer spacing to undergo less reproductive growth.

\subsubsection{Ear Length $(\mathrm{cm})$}

The main effect of varieties had a significant $(\mathrm{p}<0.01)$ effect on ear length while the other effects were not significant. Accordingly, higher ear length $(16.71 \mathrm{~cm})$ was produced from variety BH-661 while shorter ear length $(14.77 \mathrm{~cm})$ was produced from BH-QPY-545 (Table 5). Variations in ear length observed might be due to maize hybrids could have different varietal characteristics for this trait. This result is in line with the findings of [28] and [29] whore ported that variations in ear characteristics of maize depend upon genotype and environmental 
Table 5. Mean values of ear length, ear diameter and number of kernels as affected by variety and year.

\begin{tabular}{cccc}
\hline Maize variety & Ear length $(\mathrm{cm})$ & Ear diameter $(\mathrm{cm})$ & Number of kernels per ear \\
\hline BH-QPY-545 & $4.77^{\mathrm{b}}$ & $4.19^{\mathrm{b}}$ & $537.4^{\mathrm{a}}$ \\
BH-661 & $16.71^{\mathrm{a}}$ & $4.45^{\mathrm{a}}$ & $505.2^{\mathrm{b}}$ \\
LSD (0.05) & 0.45 & 0.10 & 25.74 \\
Year & & & \\
2015 & 15.86 & $4.16^{\mathrm{b}}$ & $538.8^{\mathrm{a}}$ \\
2016 & 15.62 & $4.45^{\mathrm{a}}$ & $503.8^{\mathrm{b}}$ \\
LSD (0.05) & $\mathrm{NS}$ & 0.10 & 25.74 \\
CV (\%) & 6.1 & 4.90 & 10.40 \\
\hline
\end{tabular}

Means in the table followed with the same letter(s) are not significantly different from each other at a 5\% level of significance. LSD (0.05) $=$ Least Significance Difference at $5 \%$ probability level; CV $=$ Coefficient of Variation; NS $=$ Non-Significant.

conditions. [30] reported a significant difference among the varieties of maize on ear length. [27] also reported that the longest ear length $(18.87 \mathrm{~cm})$ was found from hybrid $31 \mathrm{R} 88$ and followed by $30 \mathrm{Y} 87(17.52 \mathrm{~cm})$.

\subsubsection{Ear Diameter (cm)}

The main effects of variety and year had significant $(\mathrm{p}<0.01)$ effect on ear diameter, whereas other effects were non-significant where higher ear diameter $(4.45 \mathrm{~cm})$ was obtained from variety BH-661 variety BH-QPY-545 (Table 5). The possible reason for observed thicker ear diameters for variety BH-661 might be due to large kernel size for variety BH-661 as compared to variety BH-QPY-545. In line with this result, [31] reported that ear diameter was differed according to hybrids and the thickest ears $(4.9 \mathrm{~cm})$ were obtained from Pioneer 3223 and the thinnest one $(4.4 \mathrm{~cm})$ was obtained from DeKalb 711. Similarly, [32] revealed that the thickest ear diameter $(4.5 \mathrm{~cm})$ was obtained from SC-504 hybrid and the thinnest ear diameter $(3.8 \mathrm{~cm})$ was attained from a DC-370 hybrid. The ear diameter also differed in a different growing season where thicker ear diameter $(4.49 \mathrm{~cm})$ was produced in 2015 cropping season than in $2016(4.16 \mathrm{~cm})$ (Table $3)$.

\subsubsection{Number of Kernels per Ear}

Number of kernels per ear contributes to the economic yield and represents the productive efficiency of any cereal crop or crop variety. Number of kernels per ear were significantly $(p<0.01)$ affected by the main effects of variety and year-but there were no two or three-way interactions effects $(P>0.05)$ between or among the experimental variables. Significantly, a higher number of kernels per ear (537.4) was recorded from variety BH-QPY-545 than variety BH-661 (505.2) (Table 5). In fact, variety BH-QPY-545 gave a significantly higher number of kernels per ear than variety BH-661. The difference in number of kernels per ear observed between two varieties might be due to the fact that number of 
kernels per ear depends on traits like ear diameter, ear length and kernel size, which are genetically controlled so that variety BH-QPY-545 had smaller kernel size, which contributed to a higher number of kernels per ear as compared to variety BH-661. Similarly, [13] reported found that the variety $\mathrm{BH}-140$ gave the highest (502) number of kernels per ear (502) than varieties BHPQY-545 and BH-540 owing to the difference in genetic makeup among the cultivars. Number of kernels per ear also significantly affected by cropping season where significantly higher number of kernels per ear (538.8) was obtained in 2016 cropping season as compared to 2015 cropping season (503.8). The higher number of kernels per ear in 2016 growing season might be due to the presence of ample rainfall throughout the growing season.

\subsubsection{Thousand Kernels Weight (g)}

Thousand kernels weight is a major yield component that has an essential role in determining the potential yield of variety [27]. Three-way interaction of variety $\times$ inter-row $x$ year had significant $(p<0.05)$ effect on thousand kernels weight. In 2016 cropping season variety $\mathrm{BH}-661$ gave the highest thousand kernels weight $(448.8 \mathrm{~g})$ at wider inter-row spacing $(75 \mathrm{~cm})$, while the lowest thousand kernels weight (268.8 g) was obtained from variety BH-QPY-545 in 2015 cropping season at closer inter-row spacing of $65 \mathrm{~cm}$ (Table 6). This result indicated that variety BH-661 was more efficient to convert solar radiation and other growth resources into economic yield as compared to variety BH-QPY-545 due to its long grain filling period or late maturity. The higher thousand kernels weight at the wider inter-row spacing might also be due to availability of more resources (light, nutrient, water) for comparatively less number of plants, which they utilized efficiently to produce bigger kernels. In agreement with this result, [33] reported that thousand kernels weight is more stable than the other yield components, variation in kernel size influences kernel yield and it reacts differently to alteration in the post-flowering source-sink ratio throughout seed filling. Likewise, [34] suggested that the shorter grain filling period might have contributed to a decrease in thousand kernels weight. Thousand kernels weight

Table 6. Means of thousand kernels weight as affected by interaction effect of variety, inter-row spacing and years.

\begin{tabular}{cccc}
\hline \multirow{2}{*}{ Variety } & Inter row spacing $(\mathrm{cm})$ & \multicolumn{2}{c}{ Year } \\
\cline { 3 - 4 } & 65 & 2015 & 2016 \\
\hline \multirow{2}{*}{ BH-QPY-545 } & 75 & $315.9^{\mathrm{b}}$ & $268.8^{\mathrm{a}}$ \\
& 65 & $405.7^{\mathrm{d}}$ & $374.1^{\mathrm{d}}$ \\
\hline \multirow{2}{*}{ BH-661 } & 75 & $412.0^{\mathrm{d}}$ & $448.8^{\mathrm{d}}$ \\
& & &
\end{tabular}

$\operatorname{LSD}(0.05)=29.79 ; \mathrm{CV}(\%)=9.0$

Means in the table followed with the same letter(s) are not significantly different from each other at $5 \%$ level of significance. LSD (0.05) = Least Significance Difference at $5 \%$ probability level; CV = Coefficient of Variation. 
is a trait, which is more dependent on the genetic characteristics of varieties, and it is less affected by environmental factors [24].

\subsubsection{Aboveground Dry Biomass Yield ( $\left(\cdot \mathrm{ha}^{-1}\right)$}

Combined analysis of variance revealed that interaction effect of variety $\times$ year as well as inter $\times$ intra row spacing $\times$ year had a significant $(p<0.0)$ effect on aboveground biomass yield. The highest aboveground dry biomass yield (31.36 t.ha ${ }^{-1}$ ) was recorded for variety BH-661 in 2016 cropping season whereas the lowest aboveground dry biomass yield $\left(20.19 \mathrm{t} \cdot \mathrm{ha}^{-1}\right)$ was obtained from variety BH-QPY-545 in 2015 cropping season (Table 7). The higher aboveground biomass yield for variety $\mathrm{BH}-661$ could be due to its tallness as well as its late maturity the variety had a better chance to utilize more nutrients and more photosynthetic activity, which ultimately resulted in higher biomass production. In fact, both varieties gave significantly higher aboveground dry biomass yield in 2016 cropping season than in 2015 cropping season. This difference might be possibly due to the presence of better total amount and seasonal distribution of rainfall in 2016.

Significant disparity also depicted in the three-way interaction of inter $\times$ intra row spacing $\times$ year. Accordingly, the highest aboveground dry biomass yield $\left(31.29 \mathrm{t} \cdot \mathrm{ha}^{-1}\right)$ was obtained at wider inter $(75 \mathrm{~cm})$ and closest intra $(25 \mathrm{~cm})$ row spacing in 2016 cropping season while the lowest aboveground dry biomass $\left(19.35 \mathrm{t} \cdot \mathrm{ha}^{-1}\right)$ was attained at wider inter $(75 \mathrm{~cm})$ and widest intra $(25 \mathrm{~cm})$ row spacing in 2015 growing season (Table 8 ). The highest aboveground dry biomass of variety BH-661 at $65 \mathrm{~cm}$ inter-row spacing might be due to the presence of high number of plant stand per unit area and the late maturity of the variety that took more days to maturity and, hence had a better chance to utilize more nutrients and more photosynthetic activity, which ultimately resulted in higher biomass production. This result was in line with [33] who found that the highest aboveground dry biomass yield $\left(21.54 \mathrm{t} \cdot \mathrm{ha}^{-1}\right)$ for late maturing cultivar Ehsan, while the lowest aboveground dry biomass yield $\left(16.83 \mathrm{t} \cdot \mathrm{ha}^{-1}\right)$ was obtained from early maturing cultivar Pahari of maize. Similarly, [13] reported the highest dry biomass $\left(28.4 \mathrm{t} \cdot \mathrm{ha}^{-1}\right)$ of maize at the plant density of 61,538 plants $\cdot \mathrm{ha}^{-1}(65 \mathrm{~cm} \times$ $25 \mathrm{~cm})$, but the lowest dry biomass $\left(21.19 \mathrm{t} \cdot \mathrm{ha}^{-1}\right)$ at plant density of 44,444 plants

Table 7. Mean aboveground biomass yield and harvest index of maize as affected by the interaction effect of variety and year.

\begin{tabular}{ccccc}
\hline \multirow{2}{*}{ Maize variety } & \multicolumn{2}{c}{ Aboveground biomass yield (t/ha) } & \multicolumn{2}{c}{ Harvest index (\%) } \\
\cline { 2 - 5 } & 2015 & 2016 & 2015 & 2016 \\
\hline BH-QPY-545 & $20.19^{\mathrm{a}}$ & $24.46^{\mathrm{b}}$ & $47^{\mathrm{d}}$ & $42^{\mathrm{b}}$ \\
BH-661 & $22.59^{\mathrm{ab}}$ & $31.36^{\mathrm{c}}$ & $44^{\mathrm{c}}$ & $36^{\mathrm{a}}$ \\
& LSD $(0.05)=2.80 ; \mathrm{CV}(\%)=16.9$ & & \\
\end{tabular}

Means in the table followed with the same letter(s) are not significantly different from each other at $5 \%$ level of significance. LSD $(0.05)=$ Least Significance Difference at $5 \%$ probability level; CV = Coefficient of Variation. 
Table 8. Mean values of aboveground biomass yield and grain yield as influenced by three-way interaction of inter $\times$ intra row spacing and years respectively.

\begin{tabular}{|c|c|c|c|c|}
\hline \multicolumn{5}{|c|}{ Intra row spacing $(\mathrm{cm})$} \\
\hline Year & Inter-row spacing $(\mathrm{cm})$ & 25 & 30 & 35 \\
\hline \multicolumn{5}{|c|}{ Aboveground biomass yield $\left(\mathrm{t} \cdot \mathrm{ha}^{-1}\right)$} \\
\hline \multirow{2}{*}{2015} & 65 & $24.77^{\mathrm{cd}}$ & $20.49^{\mathrm{ab}}$ & $21.86^{\mathrm{abc}}$ \\
\hline & 75 & $19.61^{\mathrm{e}}$ & $22.28^{\mathrm{abc}}$ & $19.35^{\mathrm{a}}$ \\
\hline \multirow{3}{*}{2016} & 65 & $25.74^{\mathrm{cd}}$ & $29.32^{\mathrm{de}}$ & $28.02^{\mathrm{de}}$ \\
\hline & 75 & $31.29^{\mathrm{e}}$ & $25.84^{\mathrm{cd}}$ & $27.25^{\mathrm{de}}$ \\
\hline & \multicolumn{4}{|c|}{$\operatorname{LSD}(0.05)=4.85 ; \mathrm{CV}(\%)=16.9$} \\
\hline \multicolumn{5}{|c|}{ Grain yield $\left(t \cdot h a^{-1}\right)$} \\
\hline \multirow{2}{*}{2015} & 65 & $11.20^{\mathrm{de}}$ & $9.36^{\mathrm{abc}}$ & $9.60^{\mathrm{abcd}}$ \\
\hline & 75 & $8.99^{\mathrm{ab}}$ & $10.35^{\text {abcde }}$ & $8.66^{\mathrm{a}}$ \\
\hline \multirow{3}{*}{2016} & 65 & $9.98^{\mathrm{abcde}}$ & $11.09^{\text {cde }}$ & $10.73^{\text {bcde }}$ \\
\hline & 75 & $11.67^{\mathrm{e}}$ & $10.07^{\text {abcde }}$ & $10.22^{\mathrm{abcde}}$ \\
\hline & \multicolumn{4}{|c|}{$\operatorname{LSD}(0.05)=1.79 ; \mathrm{CV}(\%)=15.20$} \\
\hline
\end{tabular}

Means in the table followed with the same letter(s) are not significantly different from each other at a $5 \%$ level of significance. LSD $(0.05)=$ Least Significance Difference at $5 \%$ probability level; CV $=$ Coefficient of Variation.

$\mathrm{ha}^{-1}(75 \mathrm{~cm} \times 30 \mathrm{~cm})$ which might be due to the result of variation in the crop stand per unit area.

\subsubsection{Grain Yield (t.ha-1)}

Grain yield was significantly $(\mathrm{p}<0.01)$ affected by the interactions of variety $\times$ inter-row spacing and inter-row $\times$ intra row spacing $\times$ year. Accordingly, the highest grain yield $\left(11.67 \mathrm{t} \cdot \mathrm{ha}^{-1}\right)$ was obtained in combination of $75 \mathrm{~cm} \times 25 \mathrm{~cm}$ in 2016 cropping season, while the lowest grain yield $\left(8.66 \mathrm{t} \cdot \mathrm{ha}^{-1}\right)$ was obtained at wider inter and widest intra row spacing combination $(75 \mathrm{~cm} \times 35 \mathrm{~cm})$ in 2015 cropping season (Table 8). The possible reason for the lowest grain yield at widest spacing might be due to the presence of less number of plants per unit. This indicated that low plant density per unit area that could get better available growth factors like moisture, nutrients, light, and space could not offset the grain yield obtained from high plant density per unit area. Previous research findings also indicated that plants grown on wider spacing absorb more nutrients and solar radiation for improved photosynthesis and hence produce better grain yield on an individual basis but yield per unit area reduced due to a thin or low plant stand [33]. In contrast to this result, [19] reported the maximum grain yield $\left(2.6 \mathrm{t} \cdot \mathrm{ha}^{-1}\right)$ from 60,000 plants $\cdot \mathrm{ha}^{-1}$ and the lowest $\left(0.8 \mathrm{t} \cdot \mathrm{ha} \mathrm{a}^{-1}\right)$ from 140,000 plants.ha ${ }^{-1}$ of maize and attributed this to availability of more resources (nutrient + water) for comparatively less number of plants which they utilized efficiently. On the other hand, [35] revealed that plant populations that are higher 
than the optimum will lead to competition among the maize plants resulting into thin plants that will give low yield, while lower plant populations will result into low yields (though with bigger ear) due to reduced number of ears per unit area. [36] also obtained the highest grain yield $\left(3.23 \mathrm{t} \cdot \mathrm{ha}^{-1}\right)$ from one plant per hill and $25 \mathrm{~cm}$ intra-row spacing with plant density of 53333 plants.ha ${ }^{-1}$, while the lowest grain yield $\left(1.43 \mathrm{t} \cdot \mathrm{ha}^{-1}\right)$ was recorded from three plants per hill and 25

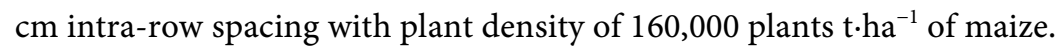

Combined analysis of variance also depicted that the interaction effect of variety by inter-row spacing had a significant effect on grain yield. Accordingly, the maximum grain yield (11.09 th $\left.\mathrm{ha}^{-1}\right)$ was obtained from variety BH-661 at a closer inter-row spacing $(65 \mathrm{~cm})$ while the minimum grain yield $\left(9.57 \mathrm{t} \cdot \mathrm{ha}^{-1}\right)$ was obtained from variety BH-QPY-545 in the same inter-row spacing (Table 4). The maximum grain yield obtained at closer spacing might be due to the presence of high plant stands per unit area resulting in high grain yield at closer inter-row spacing. Similarly, [33] stated that the highest grain yield at highest plant density (90,000 plants.ha ${ }^{-1}$ ) and attributed this to a large number of plants $\mathrm{m}^{-2}$ which compensated the effects of a decrease in other yield components like grain weight, ears plant ${ }^{-1}$ and grains ear ${ }^{-1}$ of maize. [37] also reported that the highest grain yield of maize $\left(14.71 \mathrm{t} \cdot \mathrm{ha}^{-1}\right)$ was obtained by Pashion variety at $55 \mathrm{~cm} \times 30$ $\mathrm{cm}$ spacing $\left(60,000\right.$ plants.ha $\left.\mathrm{a}^{-1}\right)$ and the lowest one $\left(8.720 \mathrm{t} \cdot \mathrm{ha}^{-1}\right)$ was obtained by Challenger variety at $75 \mathrm{~cm} \times 18 \mathrm{~cm}$ spacing $\left(75,000\right.$ plants.ha $\left.{ }^{-1}\right)$.

\subsubsection{Harvest Index (\%)}

Harvest index is the physiological efficiency of a plant for changing the total dry matter into economic yield [36]. Harvest index was significantly $(\mathrm{p}<0.05)$ affected due to interaction effect of variety $x$ inter-row spacing. Therefore, the highest harvest index (47\%) was obtained from variety BH-QPY-545 in 2016 cropping season while the lowest harvest index (36\%) was attained from variety BH-661 in 2015 cropping season (Table 7). The highest harvest index for variety BH-QPY-545 could be due to the fact that variety BH-QPY-545 had effective utilization of growth factors like moisture, nutrients, light, and space when there is adequate rainfall resulted in high photosynthesis activity and thereby to high partitioning of photosynthate into grain yield as compared to variety BH-661 due to less mutual shading effect. Likewise, the presence of small leaf size, fewer numbers of leaves, and relatively thin stalks in variety BH-QPY-545 might be a reason for low above-ground dry biomass yield that might have resulted in highest harvest index. Generally, both varieties revealed significantly higher harvest index in 2016 cropping than in 2015 cropping season which could be due to the presence of better amount and distribution of rainfall in 2016 cropping season. In agreement with this result, [38] reported that the harvest index varied significantly among different cultivars of maize. Moreover, [39] found that harvest index of the early maturating hybrid maize was higher $(41.3 \%)$ than the mid (40.3\%) and late (30.1\%) maturities of maize hybrids at $40 \mathrm{~cm}$ inter-row spacing, due to the late maturing maize hybrid might have produced more bio- 
mass yield than the grain yield.

\section{Conclusion}

Developments of recommendations for appropriate inter and intra row spacing for each variety are important agronomic practices to increase the productivity of maize. The results depicted that the main effect of variety had a significant effect on almost all parameters of maize hybrids. A number of kernels per ear was significantly affected by the main effect of variety and year. Therefore, a higher number of kernels per ear (537.4) was recorded from variety BH-QPY-545 as well as a higher number of kernels per ear (538.8) was obtained in 2016 cropping season. Interaction effect of variety, inter-row spacing and year, had a significant effect on thousand kernels weight. The highest thousand kernels weight ( $448.8 \mathrm{~g}$ ) was found from variety BH-661 at wider inter-row spacing $(75 \mathrm{~cm})$ in the 2017 cropping season. Aboveground, dry biomass yield and harvest index were significantly influenced by the interaction effect of variety by year. The highest aboveground dry biomass yield (31.36 th $\left.\cdot \mathrm{a}^{-1}\right)$ and harvest index (47\%) were obtained for varieties BH-661 and BH-QPY-545, in 2016 and 2015 cropping seasons respectively. Interaction effect of variety by inter-row spacing had a significant effect on grain yield. Accordingly, the maximum grain yield (11.09 $\left.\mathrm{t} \cdot \mathrm{ha}^{-1}\right)$ was obtained from variety BH-661 at a closer inter-row spacing $(65 \mathrm{~cm})$ and interaction effects of inter $\times$ intra row spacing $\times$ year had a significant effect on above ground dry biomass yield and grain yield. The greatest aboveground dry biomass yield $\left(31.29 \mathrm{t} \cdot \mathrm{ha}^{-1}\right)$ and grain yield $\left(11.67 \mathrm{t} \cdot \mathrm{ha}^{-1}\right)$ were obtained in the combination of $75 \mathrm{~cm} \times 25 \mathrm{~cm}$ in the 2016 cropping season. Besides, the interaction effect of variety $\times$ inter-row spacing had also a significant effect on grain yield. The greatest grain yield $\left(11.08 \mathrm{t} \cdot \mathrm{ha}^{-1}\right)$ was obtained from the variety $\mathrm{BH}-661$ at closer inter-row spacing $(65 \mathrm{~cm})$. Therefore, from this study, it can be concluded that variety BH-661 and BH-QPY-545 gave better grain yields at 75 $\mathrm{cm} \times 25 \mathrm{~cm}$ combination in the study area.

\section{Acknowledgements}

I would like to express my deepest gratitude to Prof. Tamado Tana and Prof. Habtamu Zeleke for their critical reading of the manuscript and comments. My appreciation also goes to Elias Abrahim for his assistance in field data collection. I thank the Ethiopian Institute of Agricultural Research and Haramaya University for the financial and material support, respectively, to undertake this research.

\section{Conflicts of Interest}

The authors declare no conflicts of interest regarding the publication of this paper.

\section{References}

[1] FAOSTAT (Food and Agriculture Organization of the United Nations) (2016) Food and Agriculture Data. https://www.fao.org/faostat/en/\#home 
[2] Tolessa, B., Gobezayehu, T., Worku, M., Desalegne, Y., Mulatu, K. and Bogale, G. (1993) Genetic Improvement of Maize in Ethiopia: A Review. In: Tolessa, B. and Ransom, J.K., Eds., Proceedings of the First National Maize Workshop of Ethiopia, Addis Ababa, Ethiopia, 1322.

[3] ATA (Agricultural Transformation Agency) (2014) Annual Report. ATA, Addis Ababa, Ethiopia.

[4] CSA (Central Statistical Agency) (2018) Agricultural Sample Survey Reports on Area and Production of Major Crops. Addis Ababa, Ethiopia.

[5] Shiferaw, B., Prasanna, B., Hellin, J. and Banziger, M. (2011) Feeding a Hungry World: Past Successes and Future Challenges to Global Food Security in Maize. Food Security, 3, 307-327. https://doi.org/10.1007/s12571-011-0140-5

[6] Ahmadi, M., Wiebold, W.J., Beverlein, J.E., Eckert, D.J. and Schoper, J. (1993) Agronomic Practices that Affect Corn Kernel Characteristics. Agronomy Journal, 85, 615-619. https://doi.org/10.2134/agronj1993.00021962008500030018x

[7] Sangoi, L., Graceietti, M.A., Rampazzo, C. and Bianchetti, P. (2002) The Response of Brazilian Maize Hybrids from Different Eras to Changes in Plant Density. Field Crops Research, 79, 39-51. https://doi.org/10.1016/S0378-4290(02)00124-7

[8] Jettner, R., Loss S.P., Siddique, K.H. and Martin, L.D. (1998) Responses of Faba Bean (Vicia faba L.) to Sowing Rate in South-Western Australia. I. Seed Yield and Economic Optimum Plant Density. Australian Journal of Agricultural Research, 49, 989-998. https://doi.org/10.1071/A98002

[9] Chandrasekaran, B., Annadurai, K. and Somasundaram, E. (2010) A Text of Agronomy. Ansari Road, Daryaganj, New Delhi.

[10] Tokatlidis, I.S., Koutsika-Sotiriou, M. and Tamoutsidis, E. (2005) Benefits from Using Maize Density Independent Hybrids. Maydica, 50, 9-17.

[11] EARO (Ethiopian Agricultural Research Organization) (2004) Released Crop Varieties and Their Recommended Cultural Practices. Addis Ababa, Ethiopia.

[12] Gonzalo, M., Vyn, T.J., Holland, J.B. and Mcintre, L.M. (2006) Mapping Density Response in Maize: A Direct Approach for Testing Genotype and Treatment Interactions. Genetics, 173, 331-348. https://doi.org/10.1534/genetics.105.045757

[13] AmonaTolka (2014) Effect of Varieties and Plant Density on Yield and Yield Components of Maize (Zea mays L.) in Ofa District, Gesuba, southern Ethiopia. Haramaya University, Haramaya, Ethiopia.

[14] Argaw, A., Mekonnen, E. and Muleta, D. (2015) Agronomic Efficiency of N of Common Bean (Phaseolus vulgaris L.) in Some Representative Soils of Eastern Ethiopia. Cogent Food \& Agriculture, 1, 1-15. https://doi.org/10.1080/23311932.2015.1074790

[15] EIAR (Ethiopian Institute of Agricultural Research) (2008) National Maize Research Project, Current Research Activities, Past Achievements and Future Prospective.

[16] MoA (Ministry of Agriculture) (2011) Animal and Plant Health Regulatory Directorate: Crop Variety Register. Addis Ababa, Ethiopia.

[17] Francis, C.A., Rutger, J.N. and Palmer, A.F.E. (1969) Rapid Method for Plant Leaf Area Estimation in Maize (Zea mays L.). Crop Science, 9, 537-539. https://doi.org/10.2135/cropsci1969.0011183X000900050005x

[18] VSN International Ltd. (2012) GenStat Procedure Library Release. 15th Edition. https://www.vsni.co.uk/

[19] Ahmad, A.M., Bukhsh, H.A., Ahmad, R., Malik, A.U., Hussain, S. and Ishaque, M. (2010) Agro-Physiological Traits of Three Maize Hybrids as Influenced by Varying Plant Density. Journal of Animal and Plant Sciences, 20, 34-39. 
[20] Abuzar, M.R, Sadozai, G.U., Baloch, M.S., Baloch, A.A., Shah, I.H., Javaid, T. and Hussain, N. (2011) Effect of Plant Population Densities on the Yield of Maize. Journal of Animal and Plant Sciences, 21, 692-965.

[21] Shafi, M., Bakht, J., Ali, S., Khan, H., Khan, M.A. and Sharif, M. (2012) Effect of Planting Density on Phenology, Growth and Yield of Maize (Zea mays L.). Pakistan Journal of Botany, 44, 691-696.

[22] Azam, S., Ali, M., Amin, M., Bibi, S. and Arif, M. (2007) Effect of Plant Population on Maize Hybrids. Journal of Agricultural and Biological Science, 2, 14.

[23] Karasu, A. (2012) Effect of Nitrogen Levels on Grain Yield and Some Attributes of Some Hybrid Maize Cultivars. Bulgarian Journal of Agricultural Science, 18, 42-48.

[24] Anjorin, F.B. and Ogunniyan, D.J. (2014) Comparison of Growth and Yield Components of Five Quality Protein Maize Varieties. International Journal of Agriculture and Forestry, 4, 1-5

[25] Zamir, M.S.I., Ahmad, A.H., Javeed, H.M.R. and Latif, T. (2011) Growth and Yield Behavior of Two Maize Hybrids (Zea mays L.) Towards Different Plant Spacing. Cercetări Agronomiceîn Moldova, 146, 33-40.

[26] Moraditochaee, M., Motamed, M.K., Azarpour, E. and Khosravi Danesh, R. (2012) Effects of Nitrogen Fertilizer and Plant Density Management in Corn Farming. ARPN Journal of Agricultural and Biological Science, 7, 133-137.

[27] Dalley, C.D., Bernards, M.I. and Kells, J.J. (2006) Effect of Weed Removal Timing and Row Spacing on Soil Moisture in Corn (Zea mays L.). Weed Technology, 20, 399-409. https://doi.org/10.1614/WT-05-098R.1

[28] Konuskan, O. (2000) Effects of Plant Density on Yield and Yield Related Characters of Some Maize Hybrids Grown in Hatay Conditions as Second Crop. Mount Kenya University, Thika, Kenya.

[29] Gozubenli, H., Ulger, A.C. and Sener, O. (2001) The Effect of Different N-Dose on Grain Yield and Yield Related Characters of Some Maize Genotypes Grown as Season Crop. Journal of Agriculture, 1, 39-48.

[30] Rangarajan, A., Ingall, B., Orphanages, M. and Wolfed, D. (2002) In Row Spacing and Cultivar Affects Ear Yield and Quality of Early-Planted Sweet Corn. Hort. Technology, 12, 410-415. https://doi.org/10.21273/HORTTECH.12.3.410

[31] Sener, O., Gozubenli, H., Konuskan, O. and Kilinc, M. (2004) The Effects of Intra-Row Spacing on Grain Yield and Some Agronomic Characteristics of Maize (Zea mays L.) Hybrids. Asian Journal of Plant Sciences, 3, 429-432. https://doi.org/10.3923/ajps.2004.429.432

[32] Sharifi, S.R., Mohammed, S. and Abdolghayoum, G. (2009) Effect of Population Density on Yield and Yield Attributes of Maize Hybrids. Research Journal of Biological Sciences, 4, 375-379.

[33] Borras, L., Westgate, M.E. and Otegui, M.E. (2003) Control of Kernel Weight and Kernel Water Relations by the Post-Flowering Source-Sink Ratio in Maize. Annals of Botany, 91, 857-886. https://doi.org/10.1093/aob/mcg090

[34] Aziz, A., Hidayat, U.R. and Najibullah, K. (2007) Maize Cultivar Response to Population Density and Planting Date for Grain and Biomass Yield. Sarhad Journal of Agriculture, 23, 25-30.

[35] Asea, G., Serumaga J., Mduruma, Z., Kimenye, L. and Odeke, M. (2014) Quality Protein Maize Production and Post-Harvest Handling Handbook for East and Central Africa. Association for Strengthening Agricultural Research in the East and Central Africa, Entebbe, Uganda. 
[36] Abdikeni, A. (2015) The Effect of Intra-Row Spacing and Number of Plants Per Hill on Irrigated Maize (Zea mays L.) Production at Gode, Eastern Ethiopia. Haramaya University, Haramaya, Ethiopia.

[37] Eskandarnejad, S., Khorasan, K., Bakhtiari, S. and Heidarian, R.A. (2013) Effect of Row Spacing and Plant Density on Yield and Yield Components of Sweet Corn (Zea mays L. Saccharata) Varieties. Crop Science, 3, 81-88.

[38] Bismillah, M.K., Asif M., Aman M. and Ahmad, T. (2002) Impact of Intra-Row Spacing on Growth and Yield of Some Maize Cultivars. Journal of Research, 13, 135-138.

[39] Iptas, S. and Acar, AA. (2006) Effects of Hybrid and Row Spacing on Maize Forage Yield and Quality. Plant, Soil and Environment, 52, 515-522.

https://doi.org/10.17221/3543-PSE 